\title{
Integrated Water Resources Management (IWRM) Impacts in South West Coastal Zone of Bangladesh and Fact-Finding on Tidal River Management (TRM)
}

\author{
Fahad Khan Khadim*, Kanak Kanti Kar, Pronab Kumar Halder, \\ Md. Atiqur Rahman, A.K.M. Mostafa Morshed \\ Water Resources Division, Center for Environmental and Geographic Information Services (CEGIS), Dhaka, Bangladesh \\ Email: ${ }^{*} \mathrm{fkk} 469 @$ gmail.com
}

Received August 5, 2013; revised September 6, 2013; accepted September 29, 2013

Copyright (C) 2013 Fahad Khan Khadim et al. This is an open access article distributed under the Creative Commons Attribution License, which permits unrestricted use, distribution, and reproduction in any medium, provided the original work is properly cited.

\begin{abstract}
The south west coastal zone of Bangladesh has been affected by rampant water logging due to vulnerable climate, silted rivers and stumpy terrain; and introduction of IWRM and TRM at some places of the zone has substantially safeguarded the circumstance. This study aims to assess the benefits achieved due to implementation of IWRM in parts of Khulna and Jessore districts, and investigate some technical aspects evolving TRM. Analyses have been carried out using satellite images, RS and GIS technology, Digital Elevation Model (DEM) and field investigations. A mathematical formulation has been made to assess rate of tidal sedimentation due to TRM and selection strategies of tidal basins. The study comes up with evidences of considerable advancements in regional livelihood i.e. flood resistance, cultivated lands, cultivable area, cropping intensities and food security due to IWRM. Moreover, the technical facts established on TRM would help planners to have vivid perception regarding the process.
\end{abstract}

Keywords: IWRM; TRM; GIS; RS; Tidal Sedimentation; Water Logging; Flood Resistance; Food Security

\section{Introduction}

Water is a renewable natural resource, bearing multidimensional perspectives of ownership, business and management and in the South West coastal zone of Bangladesh; water is regarded as the most prominent driving force in regional economy [1]. The zone comprises multiple climate change vulnerabilities [2], directly affected by storm surge, drainage congestion and sea level rise due to its low terrain, with almost $62 \%$ lands up to $3 \mathrm{~m}$ elevation and $86 \%$ up to $5 \mathrm{~m}$ [1]. Increasing water demand and damages due to natural disasters have made water management a challenging task in the zone [3]. Khulna and Jessore, two districts of the zone have been facing regular drainage congestion and water logging problems for quite some time due to active channel sedimentation, reducing drainage capacity of the rivers [4]. Such a situation had seen the Government of Bangladesh $(\mathrm{GoB})$ undertaking a regional program of construction of 39 polders (covering 410,392 ha) in Khulna and part of Jessore districts in 1959, aiming at flood protection and hence, increasing crop production [5]. However, this

${ }^{*}$ Corresponding author. aggravated the sedimentation problem as flood plains were eventually de-linked from rivers and dry season flow completely diminished in the upstream regions [6]. The entire river and sediment management system was disrupted, exacerbating the water logging situation of the area [7].

Local people started voicing against the traditional custom of structural solutions [8] and bearing the circumstance, the concept of Integrated Water Resources Management (IWRM) was introduced in 1994 under a government project named Khulna Jessore Drainage Rehabilitation Program (KJDRP) [9]. IWRM was first discovered in the United States in the 1920s, but it became popular worldwide in the late 1990s [10,11]. It is an integrated process promoting coordinated development and management of water and other related resources without compromising the sustainability of ecosystem [12] and in cases where individual efforts are not enough, such an iterative, integrative and interactive bottom-up planning approach of water management is required to ensure effective outcome [13]. As part of KJDRP, the GoB implemented different structural interventions entailing construction of embankments, rubber dams and dykes; con- 
struction of regulators and flushing inlets, channel reexcavation, construction of bridges, culverts etc. and most notably an innovative practice called Tidal River Management (TRM) [14].

The major purpose of TRM is to get suspended sediment deposits gradually under a controlled system [8] and sediment management is the most challenging aspect of it [15]. It is a tool under IWRM which involves peripheral breaching at a polder to allow tidal in-flow and hence accumulate deposited sediments inside the polders to raise land elevations. This eventually improves river navigability, making the enclosed lands free from water logging. The concept is simple as shown in Figure 1. When a cut is made at an appropriate point of embankment, muddy water enters the tidal basin during high tide, depositing a portion of suspended sediments on the basin before flowing back towards the ocean during low tide.

The study has been confined to parts of Khulna and Jessore districts of the South West coastal zone of Bangladesh, covering an area of 107,205 ha with latitudes ranging from $23^{\circ} 23^{\prime} 45^{\prime \prime}$ to $22^{\circ} 47^{\prime} 52^{\prime \prime}$ and longitudes from $89^{\circ} 05^{\prime} 49^{\prime \prime}$ to $89^{\circ} 29^{\prime} 45^{\prime \prime}$. The river systems of the area include Hari, Muktessari, Bhairab, Passur, Upper Bhadra and Lower Bhadra rivers and the four distinctive seasons are dry (December to February), pre-monsoon (March to May), monsoon (June to September) and post monsoon (October and November). Location of the study area as well as the different structural interventions implemented as parts of the IWRM concept in KJDRP is shown in Figure 2.

KJDRP has partially solved the prevailing water logging and drainage congestion problems as agricultural, social and economic benefits have been achieved to some extent [16]. People affected by water logging in Jessore currently ranges from $2 \%-20 \%$, whereas in Khulna the number is around $10 \%$. However, in some of the areas of South West coastal zone, water logging is still an eminent issue. In 2011 , around $35 \%-70 \%$ population were

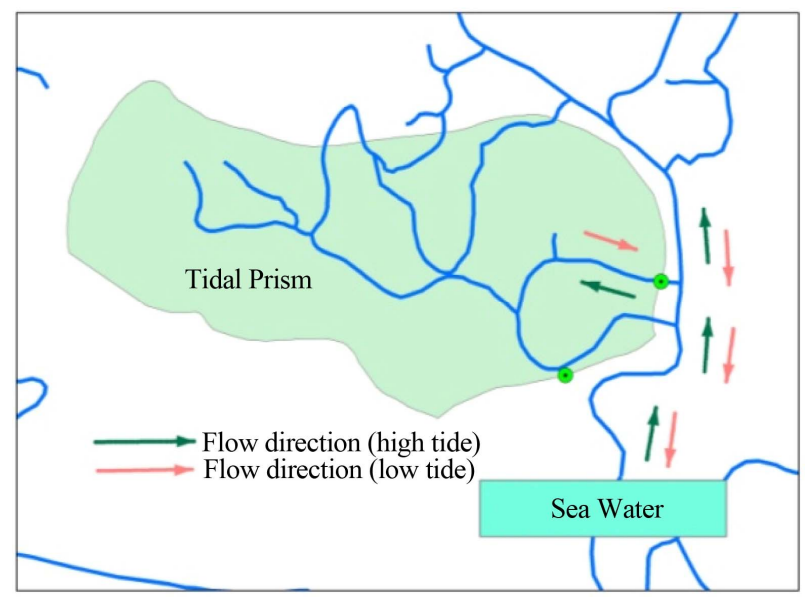

Figure 1. Tidal River Management (TRM).

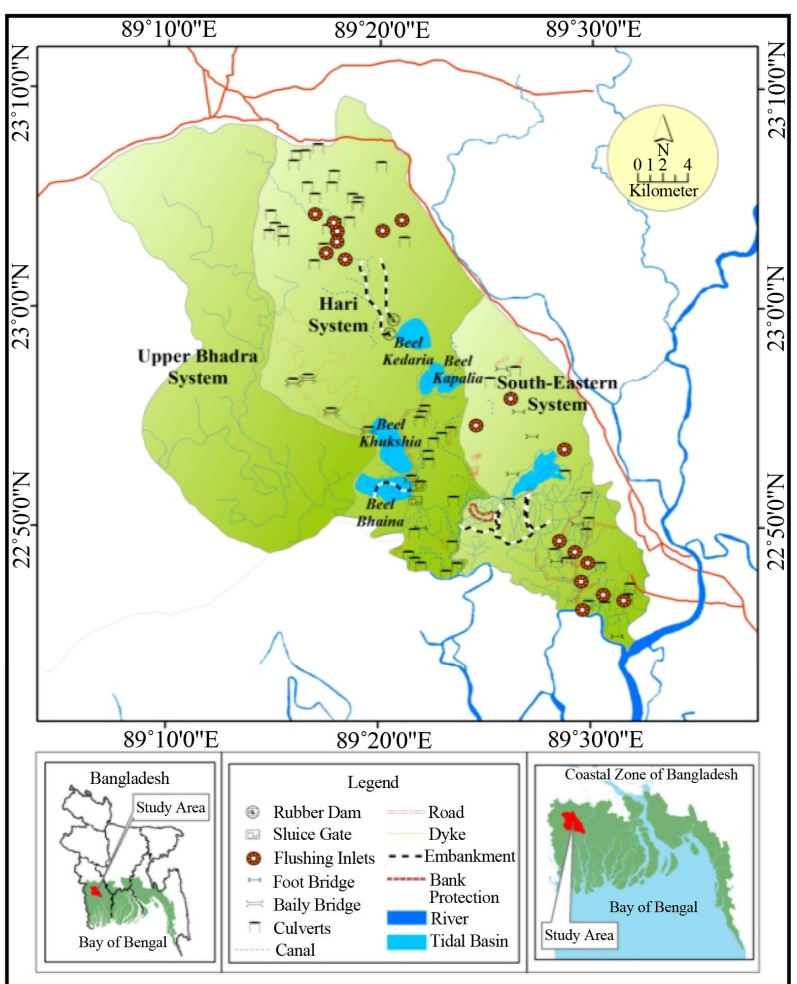

Figure 2. Study area showing different physical interventions implemented under IWRM concept since 1997.

found affected due to water logging at different sub-districts in Satkhira district (located in the West of Khulna) [17].

The study has been developed considering a twofold focus, firstly emphasizing on the positive IWRM impacts in the study area and then establishing some facts on TRM. The impacts would be helpful in clarifying the need of IWRM in regions possessing complicated water management and livelihood groups with conflicting water use. On the other hand, as TRM is an environment friendly, cost effective and economically viable process [18] to raise coastal lands for enhancing agricultural opportunities; the technical conclusions achieved in this study would be extremely helpful in providing TRM planners with information on possible TRM duration, compartment specification and sequence of tidal basin selection.

\section{Methodology and Data Assemblage}

Environmental impacts of IWRM have been studied using Remote Sensing (RS) technology, Geographic Information System (GIS) tools and Digital Elevation Models (DEMs) as well as statistical analysis of flood levels in the study area. Change in land use and water logging have been analyzed using two satellite images of 2002 and 2012. The satellite images used in this study have been collected from Indian Remote Sensing Satel- 
lite Linear Imaging Self-Scanning III (IRS P6 LISS III) and are of $24 \mathrm{~m}$ spatial resolution comprising four spectral bands i.e. Band 1 (Green: 0.52 - $0.59 \mu \mathrm{m}$ ), Band 2 (Red: 0.62 - $0.68 \mu \mathrm{m}$ ), Band 3 (Near Infra-red: 0.77 $0.86 \mu \mathrm{m}$ ) and Band 4 (Mid Infra-red: $1.55-1.70 \mu \mathrm{m}$ ). Two separate DEMs (size: 90 rows to 90 columns) of 1997 and 2011 have been used to assess land developments. The DEM of 1997 has been collected from National Water Resources Database (NWRD), Bangladesh and the DEM of 2011 has been collected from Shuttle Radar Topography Mission (SRTM) website. For accurate comparison, all topographic Reduced Levels (RLs) have been converted to Public Works Department (PWD) datum of Bangladesh, referring to a level of 0.46 below the Mean Sea Level (MSL). 50 years' information (1969 to 2009) on Highest Flood Level (HFL) have been collected at a surface water station of BWDB at Dumuria $\left(22^{\circ} 47^{\prime} 56.08^{\prime \prime} \mathrm{N}\right.$ and $\left.89^{\circ} 25^{\prime} 20.96^{\prime \prime} \mathrm{E}\right)$ sub-district, Jessore. Gumbel's probability distribution, one of the most widely used functions for extreme values of flood peaks [19] has been used for flood frequency analysis. Two flooding scenarios (of 1997 and 2011) have been developed DEM analysis and compared to investigate area's flood resistance.

Impacts on food security have been studied through assessing the changes (from 2002 to 2012) in cultivable lands, per capita food production, cropping intensity and irrigation coverage. Community based and agricultural information has been acquired from in-situ Rapid Rural Appraisals (RRAs), Focus Group Discussions (FGDs) and Key Informant Interviews (KIIs). Institutional and demographic information have been collected from subdistrict head quarters and Bangladesh Bureau of Statistics (BBS) website.

A mathematical formulation has been made using a set of geometric equations to quantify the rate of entry of Suspended Sediments (SS) in any basin due to TRM operation. If $\mathrm{dh}$ is the differential stage of tidal water in the basin (from basin bed) at a differential time $\mathrm{d} t$, the differential tidal prism can be written as $\mathrm{d} V=A^{*} \mathrm{~d} h$, where $A$ is plan area of tidal basin.

From definition of flow, mean tidal discharge in a season can be computed as, $Q=A * \frac{\mathrm{d} h}{\mathrm{~d} t}$

$$
\Rightarrow \mathrm{d} h=\frac{\left(Q_{i}^{*} \mathrm{~d} t\right)}{A}
$$

Mass of SS of the tidal prism would be,

$$
C_{i} * \mathrm{~d} V=C_{i} * A * \mathrm{~d} h,
$$

where $C_{i}$ is the mean Suspended Sediment Concentration (SSC). Therefore, differential volume of SS entering the tidal basin is,

$$
\mathrm{d} V_{\mathrm{SS}}=\frac{C_{i} * A * \mathrm{~d} h}{\rho}
$$

where $\rho$ is the density of suspended particles.

Putting d $h$ from Equation (1) to Equation (2) we get,

$$
\mathrm{d} V_{\mathrm{SS}}=\frac{C_{i} * Q_{i} * \mathrm{~d} t}{\rho}
$$

Integrating Equation (3) for the time duration " $t$ " of TRM implementation in one season, the volume of SS entering the basin during that season can be computed and then summing up these values for four different distinctive seasons we get the total volume of SS entering the basin during TRM implementation,

$$
V_{\mathrm{SS}}=\sum_{i=1}^{4} \int \frac{C_{i} * Q_{i}}{\rho} \mathrm{d} t
$$

This far, TRM has been implemented at three tidal basins of Jessore district locally named as Beel Bhaina (1997 to 2001), Beel Kedaria (2002 to 2005), Beel Khukshia (2006 to 2013) tidal basin respectively (Figure 2). Beel Bhaina underwent the first large scale TRM operation [20] from October 1, 1997 to December 31, 2001 and tidal water was allowed to enter the basin from Hari River twice a day (during high tide). The basin covered an area of 770 ha (computed from satellite image). In this study, the theoretical entry of sediments during TRM operation in Beel Bhaina tidal basin has been computed using Equation (4). Afterwards, from two DEMs of the same place and time (generated from NWRD and SRTM), an actual value of sedimentation has been determined. Comparison of the theoretical and actual values has provided an understanding of sedimentation percentage achieved due to TRM.

\section{Impacts of IWRM}

\subsection{Water Logging and Land Development}

From satellite imageries of 2002 and 2012, changes in three major land use classes (open water, agricultural land and settlements with homestead vegetation) have been measured (Table 1 and Figure 3). A substantial portion of open water areas have significantly reduced and converted to agricultural lands as well as settlements with homestead vegetation.

The information provided in Table 1 reflects developments in land use, agriculture, and socio-economy of the area and most of it has been achieved due to implementation of IWRM concept. In last ten years (2002 to 2012), extent of open water in the area has decreased by $70.13 \%$, recovering around 6 thousand hectares of land for cultivation and settlement purposes.

A separate analysis has been carried out to observe the changes in water logged areas from 2002 to 2012 (Figures 4 and 5). Due to effective implementation of IWRM, the capacity of drainage channels have increased and water logging problems in the area have been solved 


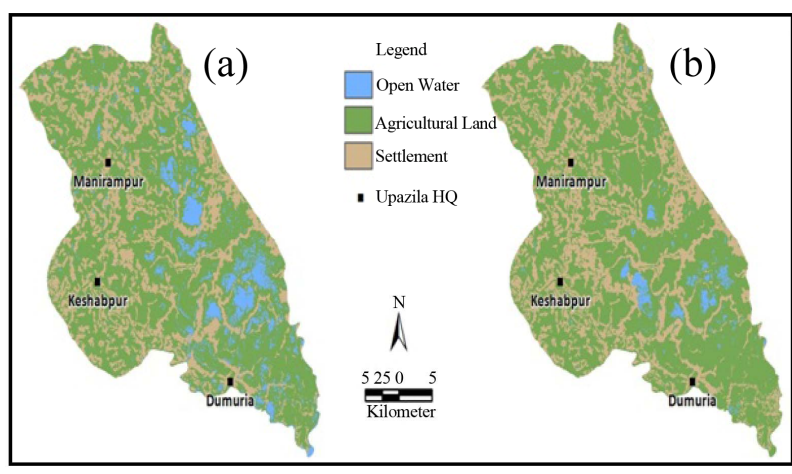

Figure 3. Land use comparison (a) 2002; (b) 2012.

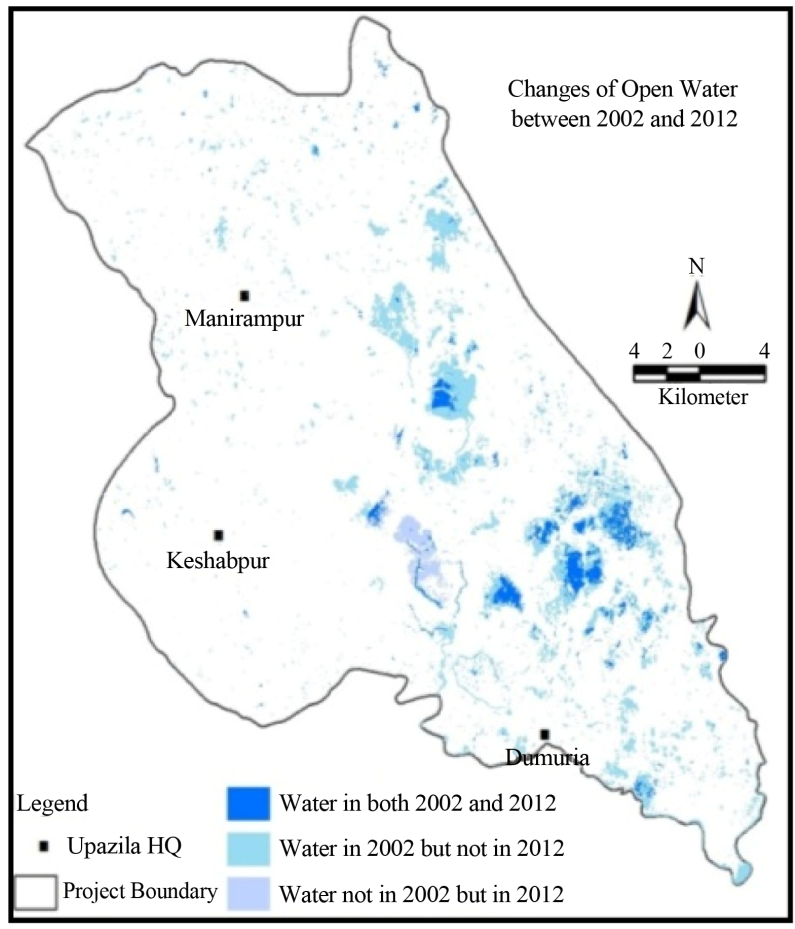

Figure 4. Changes of open water from 2002 to 2012.

Table 1. Land use change in study area.

\begin{tabular}{cccc}
\hline \multirow{2}{*}{ Class } & \multicolumn{2}{c}{ Area (ha) } & \\
\cline { 2 - 3 } & 2002 & 2012 & \\
\hline Open Water & 8558 & 2556 & $70.13 \downarrow$ \\
Agricultural Land & 68,187 & 71,543 & $4.92 \uparrow$ \\
Settlement & 30,464 & 33,111 & $8.69 \uparrow$ \\
\hline
\end{tabular}

significantly.

About $6.64 \%$ of open water areas vanished in 2012 . This was due to the land development works as well as improved river capacities of the area due to IWRM implementation.

Figure 6 explains changes in land elevations on different parts of the study area from 1997 to 2011. In 1997,

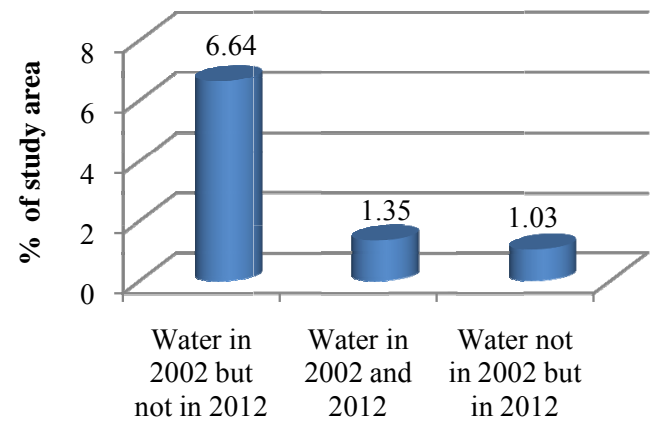

Figure 5. Changes of open water in study area between 2002 and 2012.

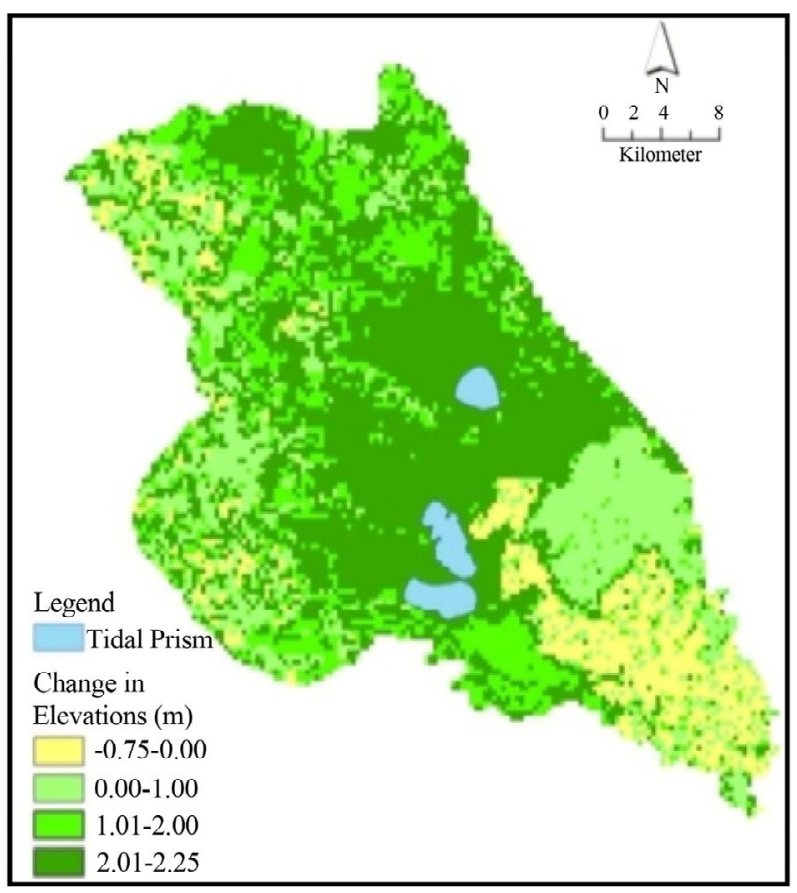

Figure 6. Changes in elevations from 1997 to 2011.

the average RL of the area was around $2.71 \mathrm{~m}+\mathrm{PWD}$, whereas in 2011, the same increased to around $4.01 \mathrm{~m}$ + PWD. Some places adjacent to the Hari River underwent direct sediment deposition from rivers and the rise in land elevations in such places has been as high as 2.25 $\mathrm{m}$.

\subsection{Flood Resistance}

The mean water levels of Hari River at Dumuria station was 2.25 - 2.65 meters during high tide and 0.2 - 0.6 meters during low tide. Table 2 below shows maximum probable flood levels of Hari River (Dumuria station) for different return periods.

The 100 year flood level obtained from Gumbel's probability analysis $(4.36 \mathrm{~m}+\mathrm{PWD})$ is found higher than almost $60 \%$ of the study area (as of 2011). To understand the change in flood resistance in the area, the 100 year 
Table 2. Extreme flood levels of Hari River (Dumuria station).

\begin{tabular}{cc}
\hline Return Period (Years) & Flood Level (m +PWD) \\
\hline 5 & 3.22 \\
10 & 3.49 \\
20 & 3.76 \\
50 & 4.10 \\
100 & 4.36 \\
\hline
\end{tabular}

flood level has been plotted against RLs of 1997 and 2011 (Figure 7).

As seen in Figure 7, significant flood resistance has been developed at some parts of the study area due to IWRM implementation as more lands are found to be free from 100 year flooding in Figure 7(b). The inundated areas for floods of other return periods have also been assessed considering the RLs of 1997 and 2011 (Figure 8).

As shown in Figure 8, the land levels which used to exist in 1997 would undergo 14\% - 16\% more flooding than that faced by the land levels of 2011. This clearly reflects the flood resistance developed in the area due to implementation of IWRM. The improvement in flooded areas developed in the study area has resulted in improved socio economic status as well as health safety of the local inhabitants.

\subsection{Food Security}

IWRM has also resulted in sustainable development of agricultural resources, triggering the agricultural production of the area and thus exploring ways to secure better food for today and tomorrow. The level of food security in the area has undergone foreseeable changes from 2002 to 2012 . Food security is measured by food availability, access, utilization and stability of a particular community [21] and these parameters depend on a number of agricultural and socio-economic indicators such as cultivable lands, per capita food production, percentage of household food expenditure, degree of access to basic needs, stability of food prices and supply etc. In this study, a few agricultural indicators which have been boosted by the implementation of IWRM are considered to assess food security.

At present, farmers grow more than one crop every year. Single cropped lands occupy around $0.4 \%$ to $14 \%$ of the entire study area. Double cropped lands occupy about 50\% - 98\% areas in five sub-districts (Batiaghata, Monirampur, Jessore Sadar, Abhaynagar, Keshabpur) of the study area and triple cropped areas occupy about $25 \%$ - 49\% areas in Jessore Sadar, Avhoynagar, Keshabpur, Monirampur and Phultala sub-districts.

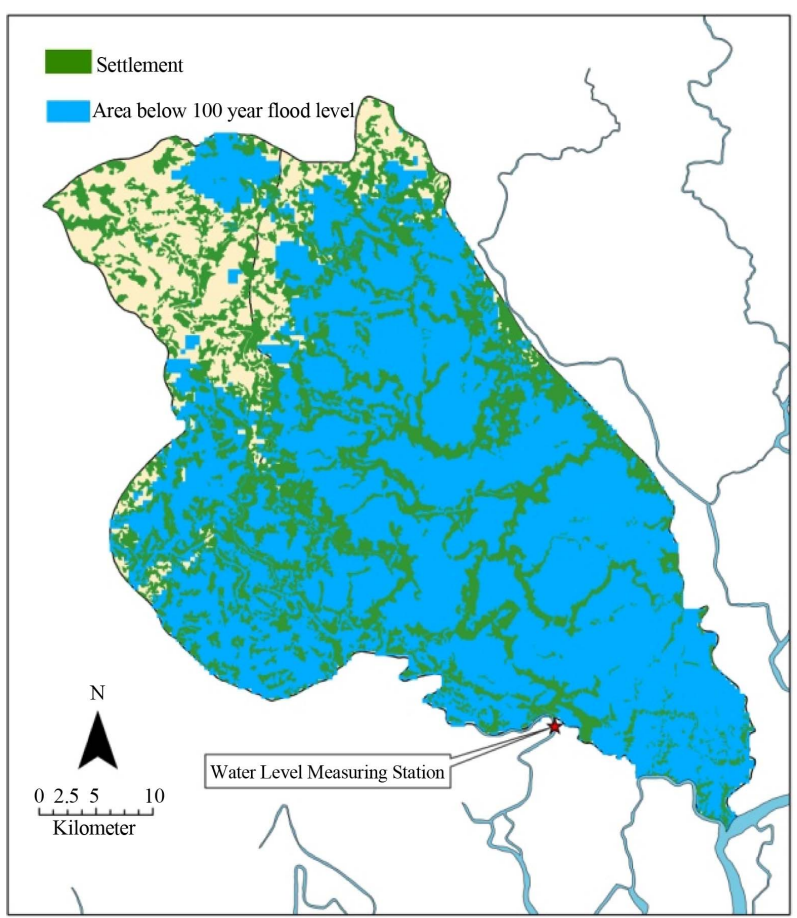

(a)

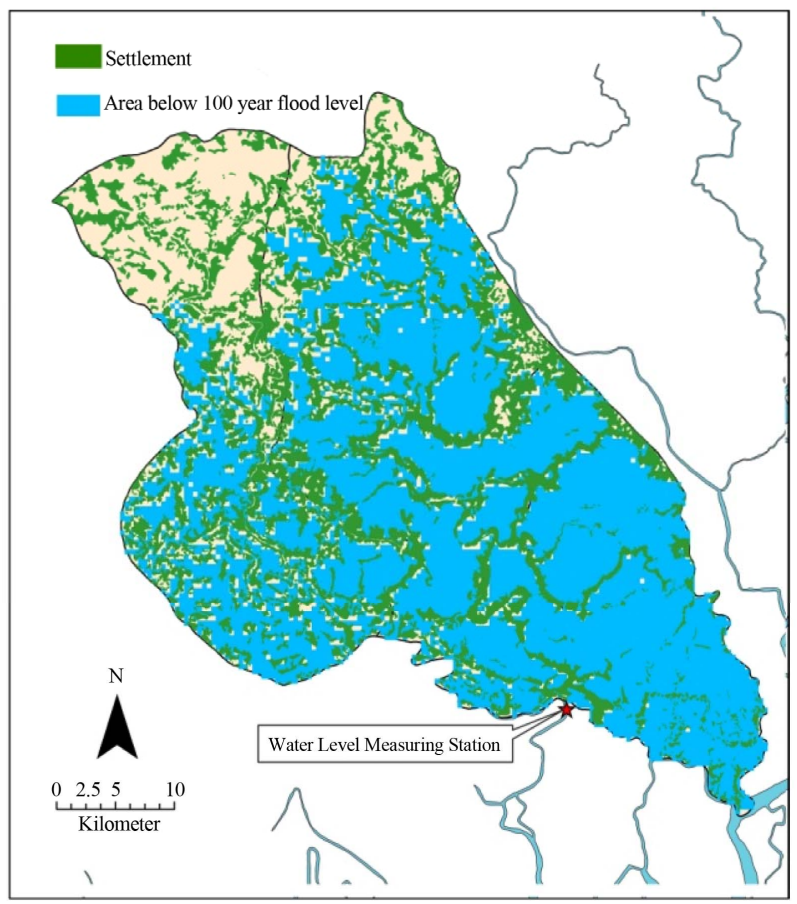

(b)

Figure 7. (a) 100 year flood against the RLs of 1997; (b) 100 year flood against the RLs of 2011.

To understand the development of food security, change in cultivated lands has been assessed in the study area for 2002 and 2012 (Figure 9). Recent trend reflects that local people have been prioritizing Rice crops (locally known as Aus, Aman and Boro) over Rabi crops 


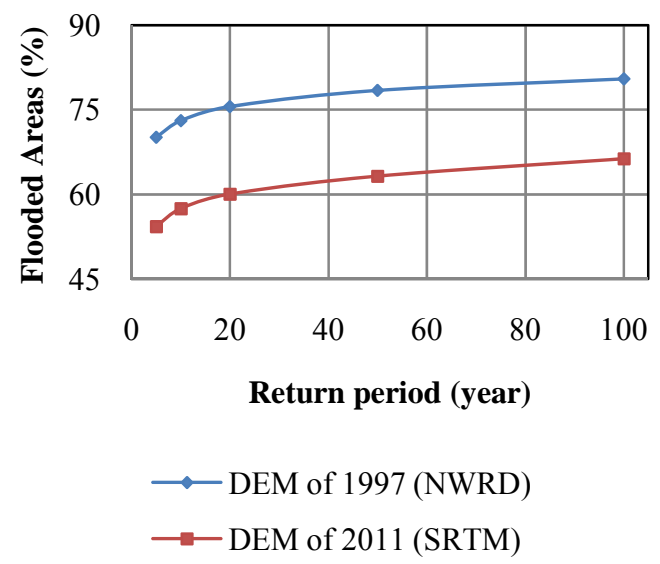

Figure 8. Flooded areas for different RLs against floods of different return periods.

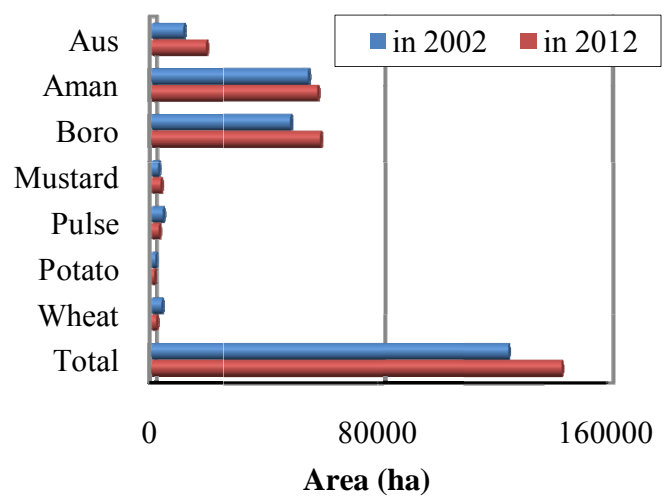

Figure 9. Changes of cultivated lands of the study area.

(locally known as Wheat, Pulse, Potato and Mustard). Overall there has been a 15\% rise (from 124, 621 ha to $143,430 \mathrm{ha})$ in total cultivated lands, reflecting on the enhanced food security.

There have been notable advancements in irrigation coverage, cropping intensity and food production in the area from 2002 to 2012 (Figure 10). Irrigation coverage has increased from $65 \%$ of Net Cultivable Area (NCA) in 2002 to $89 \%$ of NCA in 2012. Consequently, cropping intensity increased from $164 \%$ to $221 \%$ and the per capita food production increased from around 221.38 $\mathrm{kg} /$ capita to around $238 \mathrm{~kg} /$ capita, reflecting a $7.5 \%$ increase (Figure 10).

The changes in food security discussed above are partly due to the transfer of agricultural technology initiated in the area but mainly due to implementing the IWRM concept through KJDRP, which also included the community level and institutional development of local stakeholders. The increase in cultivable lands and consequent food production are the major reasons of enhanced food security in the area and these were mainly because of the various activities under IWRM process being carried out in the study area since 1997.

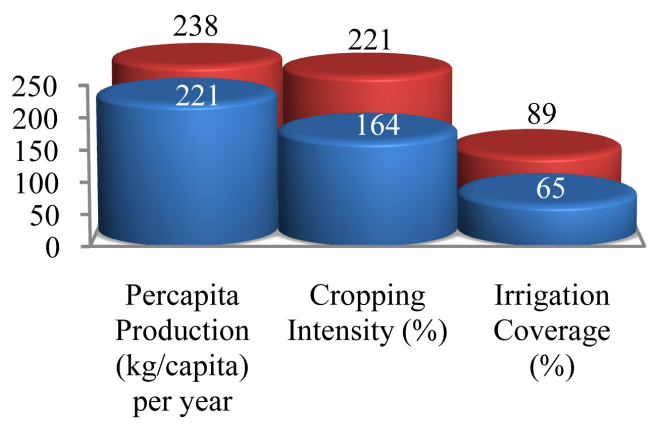

$\square \mathrm{In} 2002 \square \mathrm{In} 2012$

Figure 10. Changes in food security from 2002 to 2012.

\section{Fact-Finding on TRM}

\subsection{Sedimentation during TRM}

During TRM operation in Beel Bhaina tidal basin, the average discharges entering the basin during dry, pre monsoon, monsoon and post monsoon seasons were measured as around 160, 230, 400, $260 \mathrm{~m}^{3} / \mathrm{s}$ respectively [20]. At the same time, the mean SSC was $7.6 \mathrm{~kg} / \mathrm{m}^{3}$ [22]. Table 3 shows the amount of SS entering Beel Bhaina tidal basin during TRM operation, computed using Equation (4) and the amount of sediment deposited during the process.

The total volume of SS entering the basin during its TRM operation has been computed using Equation (4) as $52.91 \mathrm{Mm}^{3}$ (considering density of SS as 2.7). Using RLs from DEMs of 1997 and 2011 and an area of 770 ha, the actual amount of sedimentation during this period was found as $14.014 \mathrm{Mm}^{3}$, which is $26.5 \%$ of the volume of SS entering the tidal basin.

SS were originated from downstream tidal sources and remained in the form of flocks when transported by tidal flows [23,24]. The particles were held in suspension because of the turbulence of water and when the flow slowed down, cohesive sedimentation took place due to flocculation $[25,26]$.

In a study by Barua et al. 1994, it was found that in tidal rivers, tidal residual transport contributes about 53\% of the total transport [27]. In our study this number has been found to be less and this may be because of dominance of clay sized particles in the SS entering the tidal basin, only allowing cohesive sedimentation rather than sedimentation due to gravity. In another study by Datta and Subramanian 1997, the percentage of clay minerals in the lower Meghna was found as 38\% [28]. And considering this percentage of clay minerals in the river system of our study, Equation (4) can actually predict around $69.7 \%$ sedimentation.

\subsection{Sequential Selection of Tidal Basin}

TRM improves the width and navigability of involving 
Table 3. Comparison of theoretical and actual sedimentation.

\begin{tabular}{|c|c|c|c|c|c|c|c|}
\hline Season & $\begin{array}{c}\text { TRM } \\
\text { Duration, } \\
t \text { (days) }\end{array}$ & $\begin{array}{c}\text { Mean } \\
\text { discharge, } \\
Q\left(\mathrm{~m}^{3} / \mathrm{s}\right) \\
\end{array}$ & $\begin{array}{c}\text { SS entering } \\
\text { basin, } \\
V_{\mathrm{SS}}\left(\mathbf{M m}^{3}\right)\end{array}$ & $\begin{array}{c}\text { Avg. RL in } \\
\text { 1997, } \\
h_{1}(\mathrm{~m}+\mathrm{PWD})\end{array}$ & $\begin{array}{c}\text { Avg. RL in 2011, } \\
h_{2}(\mathrm{~m}+\mathrm{PWD})\end{array}$ & $\begin{array}{l}\text { SS deposited, } \\
\left(\mathrm{Mm}^{3}\right)\end{array}$ & $\begin{array}{c}\text { Percentage of } \\
\text { sedimentation } \\
(\%)\end{array}$ \\
\hline Dry (Dec-Feb) & 391 & 160 & 7.85 & & & & \\
\hline Pre-Monsoon (Mar-May) & 368 & 230 & 10.62 & & & & \\
\hline Monsoon (Jun-Sep) & 488 & 400 & 24.49 & 1.54 & 3.36 & 14.014 & 26.5 \\
\hline Post Monsoon (Oct-Nov) & 305 & 260 & 9.95 & & & & \\
\hline \multicolumn{3}{|c|}{ Total } & 52.91 & & & & \\
\hline
\end{tabular}

rivers. The Hari River, which was heavily silted up before implementation of TRM in Beel Bhaina tidal basin, was triple its width within only two years of TRM operation and its depth consequently increased to almost $10 \mathrm{~m}$ just downstream of the basin. Figure 11 shows the temporal variation of long profile of Hari River considering zero chainage from a place locally known as "Bhabadaha Regulator". The chainages of Hari River at the inlet and outlet locations of Beel Bhaina tidal basin are also shown. In July 1997, the river was shallow due to regular siltation whereas in May 2000, river bed in the immediate upstream of Beel Bhaina tidal basin dropped by $4 \mathrm{~m}$ below MSL and at some downstream locations, bed elevation dropped by around $14 \mathrm{~m}$. Due to TRM, sediments carried by the river were deposited inside the basin, causing heavy scouring river bed at downstream of Beel Bhaina tidal basin. During implementation of TRM in Beel Kedaria (after Beel Bhaina), which is located around $11 \mathrm{~km}$ downstream of Beel Bhaina, river reach along Beel Bhaina tidal basin continued to be silted up again (Figure 11).

From Equation (4) it is found that volume of SS entering a tidal basin (VSS) depends on SSC, Discharge, time and density of fine sediments and SSC remains a major driving force of TRM outcome as all the other parameters can be controlled. Observations show that at a constant shear stress in saline water, the value of SSC increases with a reduction in flow depth and vice versa [29]. Furthermore, increase in discharge per unit area increases the value of SSC [30]. Figure 11 leads us to the understanding that implementation of TRM leads to river bed scouring in downstream of the tidal basin. Therefore, when TRM is implemented in a tidal basin and the next possible TRM destination is located downstream to the existing one, a higher depth of flow would automatically be available for the next TRM basin during its TRM operation. This would allow less discharge entering per unit area into the second tidal basin (as the flow cross section at its upstream location would increase) and the value of SSC entering the basin would be reduced as well.
Additionally, the increased flow depth would also result in flow with less SSC into the second tidal basin. And from Equation (4) it can be said that due to less SSC, entry of total SS into the basin would be less and so will be the final amount of sediment deposition. Therefore, volume of SS entering a second tidal basin would not be as high as it would be if the second tidal basin was chosen upstream from the existing one.

This eventually concludes that during planning to implement TRM sequentially at a number of tidal basins, the tidal basins which are located downstream should first be subjected to TRM and the other basins located in the upstream should be brought under TRM approach respectively. After implementing TRM in Beel Bhaina, TRM was implemented in Beel Kedaria and then in Beel Khukshia (which is located in the upstream of Beel Kedaria). After that, Beel Khukshia, which is located upstream of Beel Kedaria. The next TRM destination is Beel Kapalia, which is located downstream of Beel Khukshia tidal basin (Figure 2) and this is a clear irregularity in tidal basin selection. It is understandable that selection of tidal basin does not only depend on technical aspects, choices are also influenced by socioeconomic dynamics. However, it is true that the best outcome of TRM would be achieved if tidal basins are selected from a "downstream to upstream" approach, which would help the process to accomplish desired results in due time and thus satisfy involving stakeholders.

\section{Conclusion}

IWRM concept and TRM practice are both issues generating debates and disputes regarding socio-technical benefits. The results of this study, showing the changes achieved in land development, land use, flood resistance and food security clearly reflects the positive consequences of implementing IWRM. IWRM can be extremely helpful in developing countries where water has conflicting demands and uses and ensuring stakeholder participation at all stages of planning and implementation, holistic outcomes of IWRM can be achieved. Fact-Finding of TRM covered in this study would provide planners 


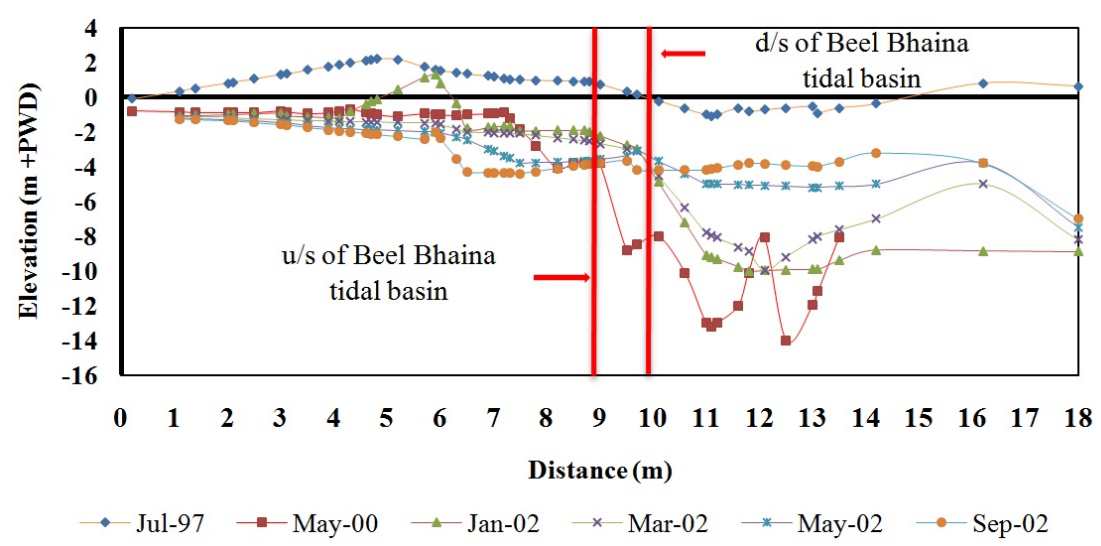

Figure 11. Long profile of Hari River from Bhabadaha regulator [20].

with a clear perception on sequential selection of tidal basins, as well as predicting the final sedimentation to some extent before implementation of TRM. The results obtained from the consideration of cohesive sedimentation in Beel Bhaina tidal basin can be modeled to predict sedimentation rates and probable duration of TRM operation and such information can satisfy both the stakeholders and implementing authorities involved in the process, resulting in best possible outcome under an arguing social context.

\section{Acknowledgements}

We would like to convey our heartiest appreciation to Center for Environmental and Geographic Information Services (CEGIS), Bangladesh for its continuous guidance and inspiration during the study. We would also like to express cordial gratitude to the people who provided important assistances and moral support in the completion of this study.

\section{REFERENCES}

[1] N. Mohal, Z. H. Khan and N. Rahman, "Impact of Sea level Rise on Coastal Rivers of Bangladesh," 9th International Conference on River Symposium and Environmental Flows, Brisbane, 4-7 September 2006, p. 66. http://archive.riversymposium.com/2006/index.php?elem ent $=06 \mathrm{MOHALNasreen}$

[2] M. R. Islam and M. Ahmad, "Living in the Coast: Problems, Opportunities and Challenges," Program Development Office, Integrated Coastal Zone Management Plan (ICZMP), Dhaka, 2004.

[3] J. U. Chowdhury, "Integrated Approach and Equity Principles to Promote Sustainable Water Management in Bangladesh," Paper Presented at the Regional Training of SAWA Fellows on Interdisciplinary Research in Water Resources Management, Bangladesh, 2010.

[4] IWM, "Mathematical Modeling Study for Planning and Design of Beel Kapalia Tidal Basin," Final Report, Bangladesh Water Development Board (BWDB), Dhaka,
2009.

[5] Aftabuzzaman, "Environmental and Socio-Economic Impacts of Coastal Embankment," Seminar on Environmental and Policy Aspects of Shrimp Cultivation, Dhaka, 28-29 August 1990.

[6] IWM, "Monitoring of Hydrological and Hydraulic Parameters on Tidal River Management under KJDRP Area," Final Report, Bangladesh Water Development Board (BWDB), Dhaka, 2005.

[7] PDO-ICZMP, "Drainage Issues in Coastal Zone," Integrated Coastal Zone Management Plan Project, Water Resources Planning Organization (WARPO), Ministry of Water Resources, The Government of Bangladesh, Dhaka, 2005.

[8] A. A. Tutu, "River Management in Bangladesh: A People's Initiative to Solve Water Logging,” PLA 51: Civil Society and Poverty Reduction, International Institute for Environment and Development (IIED), 2005.

[9] IWM, "Monitoring the Effects of Beel Khuksia TRM Basin and Dredging of Hari River for Drainage Improvement of Bhabodah Area," Final Report, Bangladesh Water Development Board (BWDB), Dhaka, 2007.

[10] Global Water Partnership (GWP), "Integrated Water Resources Management (IWRM)," TAC Background Papers (No. 4), GWP, Stockholm, 2000.

[11] A. H. Khan, "In Bangladesh Floods: Views From Home and Abroad," University Press, Dhaka, 1998.

[12] A. K. Biswas, "Integrated Water Resources Management: Is It Working?" Water Resources Development, Vol. 24, No. 1, 2008, pp. 5-22. http://dx.doi.org/10.1080/07900620701871718

[13] B. Hooper, "River Basin Organization Performance Indicators: Application to the Delaware River Basin Commission," Water Policy, Vol. 12, No. 4, 2010, pp. 1-24. http://dx.doi.org/10.2166/wp.2010.111

[14] CEGIS, "Environmental and Social Impact Assessment of Khulna Jessore Drainage Rehabilitation Project (KJDRP)," Final Report, Bangladesh Water Development Board (BWDB), Dhaka, 2007.

[15] SMEC, "Khulna Jessore Drainage Rehabilitation Project, Feasibility Study Report for Overall Drainage Plan," 
Bangladesh Water Development Board (BWDB), Dhaka, 1997.

[16] SMEC, "Khulna Jessore Drainage Rehabilitation Project," Final Report, Bangladesh Water Development Board (BWDB), Dhaka, 2002.

[17] ECB, "Flooding and Prolonged Water Logging in South West Bangladesh," Co-Ordinate Assessment Report, Emergency Capacity Building Project, Dhaka, 2011.

[18] EGIS, "Environmental and Social Impact Assessment of Khulna Jessore Drainage Rehabilitation Project," Dhaka, 1998.

[19] K. Subramanya, "Engineering Hydrology," 3rd Edition, Tata McGraw-Hill Publishing, New Delhi, 2008.

[20] CEGIS, "Monitoring and Integration of the Environmental and Socio-Economic Impacts of Implementing the Tidal River Management Option to Solve the Problem of Drainage Congestion in KJDRP Area," Final Report Part A: Monitoring and Integration, Bangladesh Water Development Board (BWDB), Dhaka, 2003.

[21] E. Masters, "Indicators of Food Security," Keynote Paper Presented of the Food and Agriculture Organization (FAO), 2009.

[22] SWMC, "Special Monitoring of Rivers and Tidal Basins for Tidal River Management of the Khulna Jessore Drainage Rehabilitation Project," Annual Report, Bangladesh Water Development Board (BWDB), Ministry of Water Resources, GoB, Dhaka, 2002.

[23] Shampa and I. M. Pramanik, "Tidal River Management (TRM) for Selected Coastal Area of Bangladesh to Mitigate Drainage Congestion," International Journal of Scientific \& Technology Research, Vol. 1, No. 5, 2012, pp 1-6.

[24] K. Kranck and T. G. Milligan, "Characteristics of Suspended Particles at an 11-Hour Anchor Station in San
Francisco Bay, California," Journal of Geophysical Research, Vol. 97, 1992, pp. 11373-11382.

http://dx.doi.org/10.1029/92JC00950

[25] J. Bartram and R. Balance, "Water Quality Monitoring-A Practical Guide to the Design and Implementation of Freshwater Quality Studies and Monitoring Programmes," UNEP/WHO, 1996.

[26] J. C. Winterwerp and W. G. M. Kesteren, "Introduction to the Physics of Cohesive Sediment in the Marine Environment," In: J. C. Winterwerp and W. G. M. van Kesteren, Eds., Developments in Sedimentology, Elsevier, Doorwerth, 2004, pp. 397-466.

[27] D. K. Barua, S. A. Kuehl, R. L. Miller and W. S. Moore, "Suspended Sediment Distribution and Residual Transport in the Coastal Ocean off the Ganges-Brahmaputra River Mouth," Marine Geology, Vol. 120, No. 1-2, 1994, pp. 41-61. http://dx.doi.org/10.1016/0025-3227(94)90076-0

[28] D. K. Datta and V. Subramanian, "Texture and Mineralogy of Sediments from the Ganges-Brahmaputra-Meghna River System in the Bengal Basin: Bangladesh and Their Environmental Implications," Environmental Geology, Vol. 30, No. 3-4, 1997, pp. 181-188. http://dx.doi.org/10.1007/s002540050145

[29] V. Chandra, P. Mohapatra and F. Nestmann, "Effect of Flow Depth, Ions, and Salinity on Suspended Sediment Concentration," Journal of Hydraulics Engineering, Vol. 138, No. 4, 2012, pp. 348-352. http://dx.doi.org/10.1061/(ASCE)HY.1943-7900.0000489

[30] A. C. Gellis, "Factors Influencing Storm Generated Suspended Sediment Concentrations and Loads in Four Basins of Contrasting Land Use, Humid Tropical Puetro Rico," CATENA, Vol. 104, 2012, pp. 39-57. http://dx.doi.org/10.1016/j.catena.2012.10.018 